E-JURNAL EKONOMI DAN BISNIS UNIVERSITAS UDAYANA
Available online at https://ojs.unud.ac.id/index.php/EEB/index
Vol. 10 No. 10, October 2021, pages: 883-896
e-ISSN: 2337-3067

\title{
PERAN LITERASI KEUANGAN DALAM MEMEDIASI PENGARUH KONTROL DIRI TERHADAP PERILAKU KONSUMTIF MAHASISWA PENGGUNA E-COMMERCE
}

\author{
Rosana Mu'amala ${ }^{1}$ Eko Wahjudi ${ }^{2}$
}

\begin{tabular}{|c|c|}
\hline Article history: & Abstract \\
\hline $\begin{array}{l}\text { Submitted: } 9 \text { Juni } 2021 \\
\text { Revised: } 9 \text { Juli } 2021 \\
\text { Accepted: } 10 \text { Juli } 2021\end{array}$ & $\begin{array}{l}\text { This study aims to analize the role of financial literacy as a } \\
\text { variable that mediates the influence of self control on the consumtive } \\
\text { behaviour of students using e-commerce. The population in this study } \\
\text { were college students of Accounting Education in Universitas Negeri } \\
\text { Surabaya that totally } 220 \text { student. The sampling technique used was }\end{array}$ \\
\hline $\begin{array}{l}\text { Keywords: } \\
\text { Self Contol; } \\
\text { Financial Literacy; } \\
\text { Consumtive Behaviour; } \\
\text { E-commerce User; }\end{array}$ & $\begin{array}{l}\text { purposive sampling and obtained a sample of } 109 \text { student. The research } \\
\text { data were obtained through a research instrument in the form of } \\
\text { questionnaire. Modelling SEM or Structural Equation Model is used as } \\
\text { research data processing technique. The result showed that: (1)there was } \\
\text { no direct effect of self control on consumtive behaviour, (2)there was a } \\
\text { significant positive direct effect of self control on financial literacy, } \\
\text { (3)there was a significant positive direct effect of financial literacy on } \\
\text { consumtive behaviour and (4)financial literacy is able to fully mediate the } \\
\text { effect of self control on consumtive behaviour of student e-commerce } \\
\text { users in the Accounting Education Program Universitas Negeri } \\
\text { Surabaya. }\end{array}$ \\
\hline
\end{tabular}

\section{Kata Kunci:}

Abstrak

Kontrol Diri;

Literasi Keuangan;

Perilaku Konsumtif;

Pengguna E-commerce;

\section{Koresponding:}

Universitas Negeri Surabaya, Jawa Timur, Indonesia Email:rosana.17080304070@ mhs.unesa.acid

\begin{tabular}{l} 
Abstrak \\
\hline Penelitian ini bertujuan untuk menganalisis peran literasi keuangan \\
sebagai variabel yang memediasi pengaruh kontrol diri terhadap perilaku \\
konsumtif mahasiswa yang menggunakan e-commerce. Populasi dalam \\
penelitian ini yaitu Mahasiswa Pendidikan Akuntansi Universitas Negeri \\
Surabaya yang berjumlah 220 mahasiswa. Teknik sampling yang digunakan \\
adalah teknik purposive sampling dan diperoleh sampel sebanyak 109 \\
mahasiswa. Data penelitian diperoleh melalui instrumen penelitian dalam \\
bentuk kuisioner. Permodelan SEM atau Structural Equation Model \\
digunakan sebagai teknik pengolahan data penelitian. Hasil penelitian \\
menunjukkan bahwa: (1)tidak terdapat pengaruh langsung kontrol diri \\
terhadap perilaku konsumtif, (2)terdapat pengaruh langsung positif \\
signifikan kontrol diri terhadap literasi keuangan, (3)terdapat pengaruh \\
langsung positif signifikan literasi keuangan terhadap perilaku konsumtif \\
serta (4)literasi keuangan mampu memediasi secara penuh pengaruh kontrol \\
diri terhadap perilaku konsumtif mahasiswa pengguna e-commerce di \\
Program Studi Pendidikan Akuntansi Universitas Negeri Surabaya.
\end{tabular}

Universitas Negeri Surabaya, Jawa Timur, Indonesia

Email: rosana.17080304070@mhs.unesa.ac.id 


\section{PENDAHULUAN}

Manusia senantiasa melakukan kegiatan konsumsi di kehidupan sehari-hari. Menurut Kartini (2010), konsumsi berasal dari kata consumtie dalam Bahasa Belanda yang diartikan sebagai suatu kegiatan memakai hingga menghabiskan nilai manfaat atau kegunaan dari suatu barang maupun jasa dengan maksud untuk memenuhi kebutuhan serta memperoleh kepuasan. Manusia yang lebih mengutamakan keinginan dibandingkan kebutuhan yang harus dipenuhinya dalam berkonsumsi biasanya dapat mendorong munculnya perilaku konsumtif (Fattah dkk. 2018). Perilaku konsumtif menurut Tambunan (2001) ialah keinginan mengkonsumsi barang-barang yang tidak begitu dibutuhkan hingga melebihi batas agar memperoleh kepuasan maksimum. Seseorang mendapat predikat konsumtif apabila membeli sesuatu secara tidak rasional atau tidak lagi mempertimbangkan faktor kebutuhan, sebab pembelian hanya didasarkan pada faktor keinginan yang berlebihan (Lina \& Rosyid, 1997).

Fenomena perilaku konsumtif dapat terjadi pada konsumen tingkat remaja, tidak hanya pada konsumen tingkat dewasa (Juliardi et al., 2018). Remaja adalah transisi dari masa anak-anak menuju usia dewasa yang mana di masa ini mereka semakin ingin bebas dan mencari jati diri (Santrock, 2017). Sikap remaja biasanya cenderung labil, mudah dipengaruhi serta senang mencoba hal baru yang kerap membuatnya berperilaku konsumtif. Remaja dapat dengan mudah tergoda oleh rayuan iklan, senang mengikuti teman, enggan realistis dan seringkali boros dalam membelanjakan uang (Hayati et al., 2020). Menurut Sukari dalam (Anggraini \& Santhoso, 2017), kecenderungan remaja untuk berperilaku konsumtif disebabkan oleh semakin banyaknya sarana maupun prasarana yang berkembang pesat seperti mall atau pusat perbelanjaan, cafe, tempat makan ataupun restoran. Remaja yang berperilaku konsumtif terbiasa membeli dan menggunakan sesuatu hanya untuk kesenangan ataupun kepuasan semata misalnya pakaian atau fashion, kosmetik, handphone, hiburan, makanan, dan lain sebagianya. Produk yang dibeli bisa jadi hanya sekedar untuk mengejar tren, meningkatkan prestise maupun alasan tidak begitu penting lainnya. Terlebih lagi beragam produk apapun kini semakin mudah diperoleh konsumen dengan adanya teknologi online system yang mendukung kegiatan transaksi online.

Salah satu teknologi online system yang kian marak digunakan konsumen dalam bertransaksi online adalah e-commerce. E-commerce sendiri diartikan sebagai tempat terjadinya pertukaran informasi atau kegiatan transaksi antara penjual maupun pembeli di dunia maya (Rerung, 2018). Keberadaan $e$ commerce mampu mempertemukan penjual dan pembeli dari seluruh dunia hanya dengan modal akses internet. Laporan Survei Alvara Beyond Insight (2019) mengungkapkan setiap tahun potensi transaksi $e$ commerce Indonesia tumbuh eksponensial yang mana transaksi e-commerce di Indonesia pada tahun 2013 terhitung sebesar US\$ 8 miliyar dan pada tahun 2016 meningkat menjadi US\$ 20 miliyar serta terus tumbuh hingga pada tahun 2020 mencapai US\$ 130 miliyar. Meningkatnya transaksi $e$-commerce tersebut selaras dengan munculnya berbagai perusahaan start up di Indonesia seperti Shoppe, Bukalapak, Lazada, Tokopedia, Blibli dan beragam jenis lainnya yang mengembangkan aplikasi e-commerce untuk mempermudah layanan transaksi maupun belanja online bagi konsumen.

Jenis e-commerce bussiness to consumer (B2C) dan consumer to consumer (C2C) dalam bentuk aplikasi digital atau sering disebut marketplace banyak digunakan untuk bertransaksi online di Indonesia terutama oleh konsumen muda. Laporan survei Alvara Beyond Insight di tahun 2020 menyebut sebanyak $57,6 \%$ masyarakat Indonesia pernah melakukan transaksi secara online lewat e-commerce dengan didominasi oleh konsumen muda millenial yang mencapai 63,8\% dari total seluruh transaksi online..

Peran Literasi Keuangan Dalam Memediasi Pengaruh Kontrol Diri Terhadap perilaku Konsumtif Mahasiswa Pengguna E-Commerce, Rosana Mu'amala dan Eko Wahjudi 
Mahasiswa yang masuk dalam kategori konsumen muda atau remaja turut pula rentan terhadap perilaku konsumtif ketika menggunakan e-commerce. Hasil studi pendahuluan peneliti terhadap 54 Mahasiswa Pendidikan Akuntansi Universitas Negeri Surabaya menemukan bahwa banyak dari mereka merupakan pengguna aktif e-commerce yang sering berbelanja online dengan persentase $25.9 \%$ mahasiswa berbelanja online sebanyak 1-2 kali tiap bulan, 14.8\% mahasiswa berbelanja online sebanyak 3-4 kali tiap bulan, $11.1 \%$ mahasiswa berbelanja online sebanyak lebih dari 5 kali tiap bulan serta sisanya 48.1\% mahasiswa berbelanja online hanya di waktu tertentu. Beberapa mahasiswa tersebut beralasan selain karena mudah dan praktis, mereka lebih memilih berbelanja di e-commerce karena sering terpengaruh oleh adanya penawaran menarik yang disediakan seperti diskon, hadiah, gratis ongkir, cashback serta fitur pembayaran paylater meskipun terkadang barang yang dibeli tidak begitu dibutuhkan. Pembelian barang yang tidak begitu dibutuhkan membuat mahasiswa pengguna e-commerce menjadi lebih konsumtif. Hal ini diperkuat oleh hasil penelitian Rachmawati (2019) yang menyebut perkembangan e-commerce mempengaruhi gaya hidup mahasiswa menjadi bergaya hidup konsumtif yang tinggi.

Perilaku konsumtif mahasiswa pengguna e-commerce diduga dapat dipengaruhi oleh faktor kontrol diri. Amelia (2019) menyebut kontrol diri merupakan prediktor yang mempengaruhi perilaku konsumtif mahasiswa dalam berbelanja online. Kontrol diri diartikan sebagai kemampuan untuk menyusun, membimbing, mengatur, dan mengarahkan bentuk perilaku yang dapat membawa ke arah konsekuensi positif (Ghufron \& Risnawita, 2010). Kemampuan dalam mengontrol diri sangat penting bagi mahasiswa pengguna e-commerce saat akan membeli sebuah produk. Menurut Anggreini \& Mariyanti (2014), mahasiswa akan mampu mempertimbangkan prioritas dalam membeli serta dapat memilih dengan baik hal-hal yang penting sebelum memutuskan membeli jika memiliki kontrol diri yang baik. Adapun e-commerce acapkali memberikan penawaran yang memikat bagi penggunanya sehingga mahasiswa pengguna e-commerce kerap tergoda untuk membeli produk. Ketika keinginan terhadap suatu produk melampaui tujuan pembelian konsumen maka pembelian impulsive dapat terjadi (Sultan, et al., 2012).

Lina \& Rosyid, (1997) menyebut pembelian impulsive termasuk salah satu aspek perilaku konsumtif. Pembelian impulsive adalah dorongan kuat yang tiba-tiba muncul dalam diri konsumen untuk segera membeli (Vohs \& Faber, 2007). Pembelian impulsive yang cenderung spontan dan reflektif memicu pembelian produk yang tidak rasional atau tidak sesuai kebutuhan sehingga bentuk kontrol diri atau kemampuan menahan diri yang baik diperlukan untuk mengatur tindakan konsumen pengguna $e$ commerce agar tidak menjadi semakin konsumtif. Penelitian terdahulu pernah dilakukan oleh Chita dkk. (2015); Dewi dkk. (2017); Tripambudi \& Indrawati (2018); Dina A. \& Rinaldi (2019); Kumalasari \& Soesilo (2019); serta Hayati et al.,(2020) yang hasilnya mengatakan bahwa kontrol diri memiliki pengaruh negatif signifikan terhadap perilaku konsumtif. Semakin baik atau tinggi kontrol diri individu maka akan semakin menurunkan perilaku konsumtifnya. Hal ini berbanding terbalik dengan penelitian Salsabila dkk. (2019) yang justru menyebut kontrol diri tidak mempunyai hubungan terhadap perilaku konsumtif Mahasiswa UBH pengguna e-commerce Shoppe.

Faktor kontrol diri selain dapat mempengaruhi perilaku konsumtif diduga pula turut mempengaruhi literasi keuangan individu secara langsung. Literasi keuangan bisa diartikan sebagai ukuran seberapa baik seseorang dalam memahami serta menggunakan informasi terkait keuangan pribadi (Huston, 2010). Literasi keuangan mengacu pada pengetahuan dan pemahaman tentang konsep keuangan

Peran Literasi Keuangan Dalam Memediasi Pengaruh Kontrol Diri Terhadap perilaku Konsumtif Mahasiswa Pengguna E-Commerce, 
sehingga menghasilkan kemampuan untuk memperoleh informasi, keyakinan dan keputusan yang efektif tentang uang (Capuano \& Ramsay, 2011). Seseorang akan mempunyai sikap serta tanggung jawab dalam pengelolaan keuangannya dengan melakukan kontrol diri sehingga pengaruh kontrol diri sangatlah penting terhadap manajemen keuangan pribadi seseorang (Roestanto, 2017). Penelitian secara konsisten pernah dilakukan oleh Susanti (2016) yang menyatakan literasi keuangan dapat dipengaruhi oleh locus of control internal.

Literasi keuangan dianggap pula menjadi faktor yang secara langsung mempengaruhi perilaku konsumtif mahasiswa pengguna e-commerce. Literasi keuangan merupakan tingkat pengetahuan, keterampilan, keyakinan yang mempengaruhi sikap dan perilaku untuk meningkatkan kualitas pengambilan keputusan dan pengelolaan keuangan dalam rangka mencapai kesejahteraan (Otoritas Jasa Keuangan, 2016). Literasi keuangan sangat berguna bagi konsumen pengguna e-commerce. Konsumen yang memiliki pengetahuan keuangan akan mampu mengelola perilaku konsumsinya (Putri dkk. 2016). Imawati dkk. (2013) menjelaskan baiknya kemampuan literasi keuangan akan membantu konsumen memilih dan memberi komplain barang dan jasa yang dikonsumsinya secara cerdas, selain itu pemahaman literasi keuangan akan membantu konsumen lebih mudah mengelola keuangannya serta membuat perencanaan di masa depan. Literasi keuangan diperlukan untuk meminimalisir tindakan konsumtif terhadap pembelian barang maupun jasa bagi pengguna e-commerce. Penelitian serupa pernah dilakukan oleh Julian dkk. (2015); Ridhayani \& Johan (2020); Dewi dkk. (2017); Imawati dkk. (2013) yang menyatakan literasi keuangan mempunyai pengaruh negatif signifikan terhadap perilaku konsumtif yang berarti meningkatnya tingkat literasi keuangan akan dapat berpengaruh terhadap menurunnya perilaku konsumtif.

Penelitian ini memiliki tiga variabel penelitian yang terdiri dari kontrol diri, literasi keuangan dan perilaku konsumtif. Kontrol diri digunakan sebagai variabel independen (X), literasi keuangan digunakan sebagai variabel mediasi (M) dan perilaku konsumtif digunakan sebagai variabel dependen (Y). Model rancangan penelitiannya dapat dilihat pada Gambar 1 berikut ini :

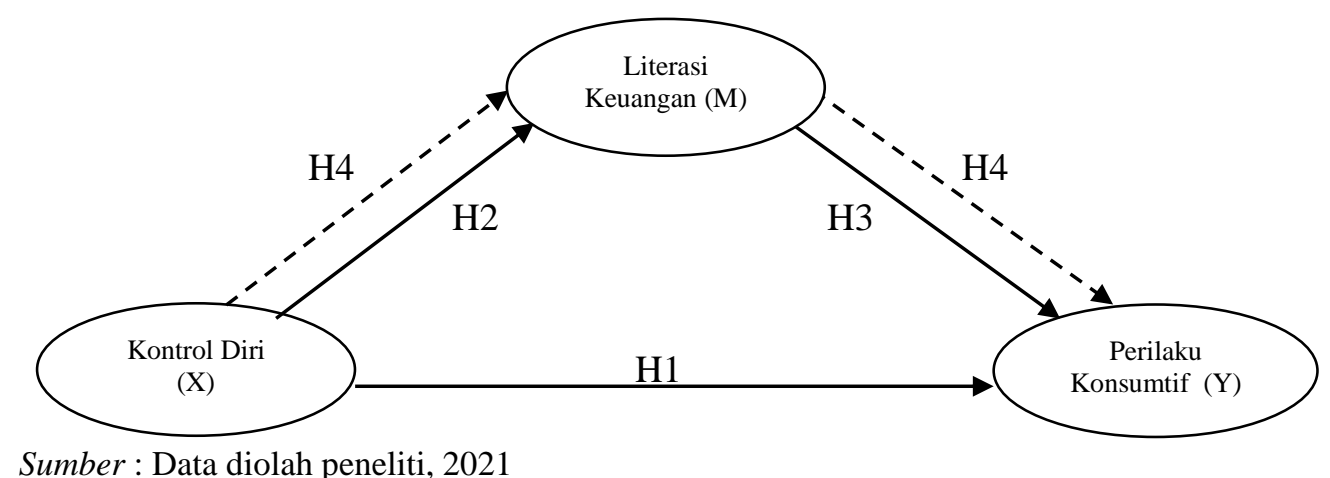

Sumber : Data diolah peneliti, 2021

\section{Gambar 1. Model Penelitian}

Variabel kontrol diri (X), variabel literasi keuangan (M) dan variabel perilaku konsumtif (Y) diukur menggunakan beberapa indikator. Variabel kontrol diri diukur menggunakan indikator aspekaspek kontrol diri yang dicetuskan Averill dalam (Ghufron \& Risnawita, 2010), yakni (1) kemampuan 
mengontrol perilaku, (2) kemampuan mengontrol stimulus, (3) kemampuan memperoleh informasi, (4) kemampuan melakukan penilaian, dan (5) kemampuan mengontrol keputusan. Variabel literasi keuangan diukur menggunakan indikator menurut Capuano \& Ramsay (2011), yakni (1) kemampuan dan keterampilan dasar seseorang dalam mengelolaan keuangan (money basic), (2) penganggaran (budgeting), (3) tabungan dan perencanaan (saving and planning), (4) pinjaman dan literasi hutang (debt literacy), (5) pemahaman produk keuangan, serta (6) recourse dan self help. Adapun indikator perilaku konsumtif diambil melalui karakteristik-karakteristik perilaku konsumtif menurut Sumartono (2002), yakni: (1) membeli produk karena iming-iming hadiah, (2) membeli produk karena kemasannya menarik, (3) membeli produk demi menjaga penampilan, (4) membeli produk atas pertimbangan harga, (5) membeli produk hanya karena simbol status, (6) memakai produk karena unsur konformitas, (7) munculnya penilaian bahwa membeli produk mahal akan menimbukan rasa percaya diri yang tinggi, serta (8) mencoba lebih dari dua produk sejenis (merek berbeda).

Tujuan penelitian ini adalah untuk menganalisis pengaruh secara langsung faktor kontrol diri terhadap perilaku konsumtif, menganalisis pengaruh secara langsung faktor kontrol diri terhadap literasi keuangan, menganalisis pengaruh secara langsung literasi keuangan terhadap perilaku konsumtif, serta menganalisis peran literasi keuangan dalam memediasi pengaruh kontrol diri terhadap perilaku konsumtif mahasiswa pengguna e-commerce di Program Studi Pendidikan Akuntansi Universitas Negeri Surabaya. Adapun berdasarkan teori dan pemaparan gap research di atas, penelitian ini membentuk beberapa hipotesis penelitian yakni : H1 : Diduga terdapat pengaruh signifikan kontrol diri terhadap perilaku konsumtif mahasiswa pengguna e-commerce di Program Studi Pendidikan Akuntansi Universitas Negeri Surabaya. H2 : Diduga terdapat pengaruh signifikan kontrol diri terhadap literasi keuangan pengguna $e$ commerce di Program Studi Pendidikan Akuntansi Universitas Negeri Surabaya. H3 : Diduga terdapat pengaruh signifikan literasi keuangan terhadap perilaku konsumtif pengguna e-commerce di Program Studi Pendidikan Akuntansi Universitas Negeri Surabaya. H4 : Diduga literasi keuangan mampu memediasi pengaruh kontrol diri terhadap perilaku konsumtif pengguna e-commerce di Program Studi Pendidikan Akuntansi Universitas Negeri Surabaya.

\section{METODE PENELITIAN}

Penelitian ini termasuk jenis penelitian kuantitatif. Metode kuantitatif dipilih karena analisis datanya menggunakan statistik (Sugiono, 2017). Populasi penelitiannya adalah seluruh Mahasiswa Pendidikan Akuntansi Universitas Negeri Surabaya angkatan 2017, 2018 dan 2019 yang berjumlah 220 mahasiswa. Jumlah sampel diperoleh sebanyak 109 mahasiswa melalui teknik purposive sampling. Kriteria sampel penelitian adalah mahasiswa yang memiliki akun aktif e-commerce serta pernah melakukan transaksi pembelian lebih dari satu kali setiap bulan di e-commerce.

Pengumpulan data dilakukan melalui instrumen penelitian berupa kuisioner. Kuisioner dalam penelitian ini memiliki lima alternatif jawaban dengan total 25 item pernyataan yang diukur menggunakan Skala Likert. Uji validitas dan reliabilitas kelayakan kuisioner dilakukan melalui program IBM Statistics SPSS 25. Hasil uji validitas kuisioner terhadap setiap item pernyataan indikator secara keseluruhan dinyatakan valid karena setiap item indikator memiliki $\mathrm{R}$ hitung > R tabel yang sebesar 0,349 serta memiliki nilai $\mathrm{p}<.0,05$. Variabel kontrol diri (X), variabel literasi keuangan (M) dan variabel

Peran Literasi Keuangan Dalam Memediasi Pengaruh Kontrol Diri Terhadap perilaku Konsumtif Mahasiswa Pengguna E-Commerce, Rosana Mu'amala dan Eko Wahjudi 
perilaku konsumtif (Y) masing-masing juga memiliki nilai Cronbach's Alpha $>$ 0,6 sehingga dapat dinyatakan reliabel.

Penelitian ini menggunakan teknik analisis data melalui analisis deskriptif dan permodelan Struktural Equation Modeling (SEM). Program WarPLS 7.0 dipilih guna membantu analisis statistik dalam penelitian. Analisis deskriptif digunakan untuk menentukan kategori atau kriteria predikat variabel kontrol diri, variabel literasi keuangan dan variabel perilaku konsumtif berdasarkan perhitungan kelas interval dari skor jawaban responden pada kuisioner. Hasil perhitungan kelas interval akan ditampilkan pada Tabel 1 di bawah ini :

Tabel 1.

Perhitungan Kelas Interval

\begin{tabular}{lccc}
\hline \multirow{2}{*}{ Keterangan } & \multicolumn{3}{c}{ Variabel Penelitian } \\
\cline { 2 - 4 } & Kontrol Diri & Literasi Keuangan & Perilaku Konsumtif \\
\hline Skor Maksimal & 25 & 60 & 40 \\
Skor Minimal & 5 & 12 & 8 \\
Selisih Skor & 20 & 48 & 32 \\
Lebar Kelas & 4 & 9.6 & 6.4 \\
Kelas I (Sangat Rendah) & $5-9$ & $12-21.6$ & $8-14.4$ \\
Kelas II (Rendah) & $>-13$ & $>21.6-31.2$ & $>14.4-20.8$ \\
Kelas III (Sedang) & $>13-17$ & $>31.2-40.8$ & $>20.8-27.2$ \\
Kelas IV (Tinggi) & $>17-21$ & $>40.8-50.4$ & $>27.2-33.6$ \\
Kelas V (Sangat Tinggi) & $>21-25$ & $>50.4-60$ & $>33.6-40$ \\
\hline
\end{tabular}

Sumber : Data diolah peneliti, 2021

Teknik analisis data dengan permodelan Struktural Equation Modeling (SEM). Permodelan Struktural Equation Modeling (SEM) dalam penelitian ini terdiri dari uji outer model, uji inner model dan uji hipotesis penelitian.

\section{HASIL DAN PEMBAHASAN}

Analisis deskriptif digunakan untuk menentukan predikat atau kategori variabel kontrol diri, variabel literasi keuangan dan variabel perilaku konsumtif mahasiswa pengguna e-commerce di Program Studi Pendidikan Akuntansi Universitas Negeri Surabaya melalui skor rata-rata kuisioner dengan melihat kriteria pada Tabel 1 Perhitungan Kelas Interval. Hasil analisis deskriptif menunjukkan tingkat kontrol diri mahasiswa pengguna e-commerce di Program Studi Pendidikan Akuntansi Universitas Negeri Surabaya memiliki predikat tinggi karena diperoleh perhitungan skor rata-rata kuisioner sebesar 20,98 yang termasuk ke dalam kriteria tinggi. Tingkat literasi keuangan mahasiswa pengguna e-commerce di Program Studi Pendidikan Akuntansi Universitas Negeri Surabaya juga dikategorikan tinggi karena perhitungan skor rata-rata kuisioner diperoleh sebesar 48.48 atau $80.79 \%$ dari skor total maksimal dan termasuk dalam kriteria tinggi. Adapun perilaku konsumtif mahasiswa pengguna e-commerce di Program 
Studi Pendidikan Akuntansi Universitas Negeri Surabaya memiliki predikat sedang karena hasil perhitungan skor rata-rata kuisioner diperoleh sebesar 22,17 yang termasuk dalam kriteria sedang.

Analisis berikutnya adalah analisis hasil pengujian outer model. Pengujian outer model meliputi uji validitas dan realibilitas instrumen penelitian (Solimun, 2017). Pengujian outer model sifatnya hanya pemeriksaan ulang (cross check) karena validitas dan realibilitas instrumen penelitian sudah dianalisis saat perancangan kuisioner dan saat uji coba serta hasil pengujiannya telah dijelaskan pada metode penelitian. Hasil pengujian outer model didasarkan dengan melihat hasil uji validitas konvergen dan uji validitas diskriminan. Terpenuhinya syarat uji validitas konvergen ialah jika setiap item indikator variabel masing-masing memiliki muatan faktor $\geq 0,6$ dan nilainya signifikan $(P$-value $<0,001)$ serta uji validitas diskriminan dinyatakan terpenuhi jika nilai loading > nilai cross loading. Hasil uji validitas konvergen menunjukkan bahwa muatan faktor dari variabel kontrol diri $(\mathrm{X})$ memiliki 1 item indikator $\leq 0.6$ yakni item X4 yang muatan faktornya sebesar 0.549 serta 2 item indikator literasi keuangan $(\mathrm{M}) \leq 0.6$ yakni item M4 yang muatan faktornya sebesar 0.508 dan M9 yang muatan faktornya sebesar 0.475 . Total item indikator seluruh variabel yang telah memenuhi uji validitas konvergen adalah 22 item indikator yang terdiri dari 4 indikator variabel kontrol diri, 10 indikator variabel literasi keuangan dan 8 item indikator variabel perilaku konsumtif karena memiliki nilai $\geq 0.6$ dan nilainya signifikan ( $P$-value $<0,001)$. Variabel kontrol diri, variabel literasi keuangan dan variabel perilaku konsumtif masing-masing memiliki nilai loading > nilai cross loading sehingga telah memenuhi validitas diskriminan.

Syarat terpenuhinya reabilitas komposit ialah nilai composite realibility $\geq 0,70$ dan reabilitas internal konsistensi terpenuhi apabila nilai koefisien Cronbach Alpha $\geq 0,6$. Hasil uji reabilitas instrumen menunjukkan nilai composite realibility variabel kontrol diri $(\mathrm{X})$ sebesar 0,821 , nilai composite realibility variabel literasi keuangan (M) sebesar 0,898 dan nilai composite realibility variabel perilaku konsumtif (Y) sebesar 0,929. Adapun nilai Cronbach Alpha variabel kontrol diri (X) sebesar 0,726, nilai Cronbach Alpha variabel literasi keuangan sebesar 0,875 dan nilai Cronbach Alpha variabel perilaku konsumtif sebesar 0,913. Hasil tersebut secara keseluruhan menunjukkan bahwa instrumen penelitian tiap variabel telah memenuhi reabilitas komposit dan reabilitas internal konsistensi sehingga dinyatakan reliabel.

Tabel 2.

Model Fit dan Quality Indices

\begin{tabular}{lcc}
\hline \multicolumn{1}{c}{ Model Fit dan Kualitas Indikator } & Kriteria Fit & Hasil Analisis \\
\hline Average Path Coefficient (APC) & $\mathrm{P}<0,05$ & $0,315, \mathrm{P}<0.001$ \\
Average R-squared (ARS) & $\mathrm{P}<0,05$ & $0.241, \mathrm{P}=0.002$ \\
Average adjusted R-squared (AARS) & $\mathrm{P}<0,05$ & $0.229, \mathrm{P}=0.003$ \\
Average block VIF (AVIF) & acceptable if $<=5$, Ideally $<=3.3$ & 1.370 \\
Average full collinearity VIF (AFVIF) & acceptable if $<=5$, Ideally $<=3.3$ & 1.507 \\
Tenenhaus GoF (Gof) & small $>=0.1$, medium $>=0.25$, & 0.356 \\
& large $>=0.36$ & \\
Sympson's paradox ratio (SPR) & acceptable if $>=0.7$, Ideally $=1$ & 0.667 \\
R-square contribution ratio (RSCR) & acceptable if $>=0.9$, Ideally $=1$ & 0,984 \\
Statistical supression ration ( SSR) & acceptable if $>=0.7$ & 1 \\
Nonlinear bivariate causality direction & acceptable if $>=0.7$ & 0.5 \\
ratio (NLBCDR) & & \\
\hline Suber:Hat & & \\
\hline
\end{tabular}

Sumber : Hasil olah WarPLS, 2021

Peran Literasi Keuangan Dalam Memediasi Pengaruh Kontrol Diri Terhadap perilaku Konsumtif Mahasiswa Pengguna E-Commerce, Rosana Mu'amala dan Eko Wahjudi 
Berdasarkan Tabel 2 di atas, seluruh hasil uji dalam penelitian ini telah memenuhi kriteria model fit kecuali nilai SPR dan nilai NLBCDR karena nilainya kurang memenuhi kriteria model fit. APC, ARS, dan AARS mempunyai nilai $P$-value $<0.05$ yang artinya signifikan sehingga termasuk dalam kategori ideal. Nilai AVIF sebesar 1.370 serta AFVIF sebesar 1.507 yang memenuhi syarat yaitu $\leq 5$, ideally $\leq 3.3$ sehingga dapat dikatakan ideal.

Berdasarkan rancangan penelitian yang telah dibuat pada metode penelitian, pengujian hipotesis menggunakan uji pengaruh langsung (direct effect) serta uji pengaruh tidak langsung (indirect effect) melalui variabel mediasi. Adapun hipotesis diterima apabila besarnya nilai p-value $<0.05$. Hasil pengujian hipotesis dapat diketahui dari hasil uji model penelitian melalui program WarPLS 7.0 yang akan ditunjukkan oleh Gambar 2 berikut ini :

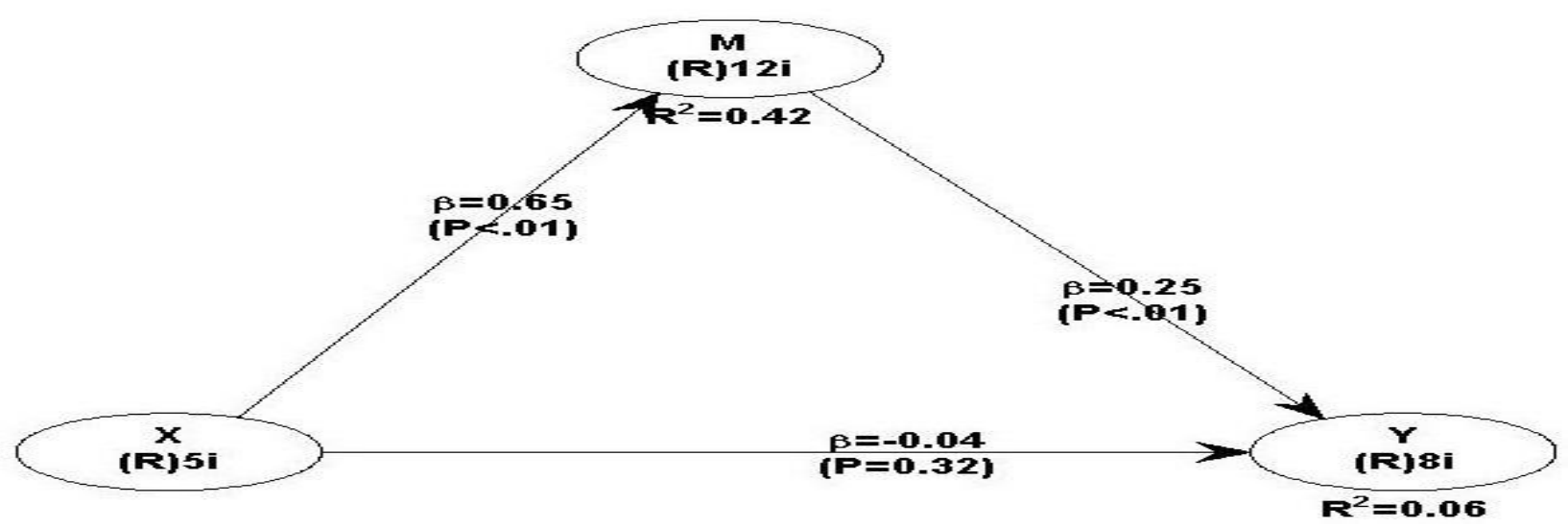

Sumber : Hasil olah WarPLS, 2021

Gambar 2.

Model Penelitian

Pengaruh langsung dalam penelitian ini terdapat pada uji H1, H2 dan H3. Hasil uji pengaruhlangsung akan ditampilkan pada Tabel 3 dan Tabel 4 berikut ini :

Tabel 3.

Path Coefficient

\begin{tabular}{lccc}
\hline \multicolumn{1}{c}{ Variabel } & Kontrol Diri & Literasi Keuangan & Perilaku Konsumtif \\
\hline Kontrol Diri & & & \\
Literasi Keuangan & 0.648 & \\
Perilaku Konsumtif & -0.045 & 0.253 \\
\hline
\end{tabular}

Sumber : Hasil olah WarPLS, 2021

Peran Literasi Keuangan Dalam Memediasi Pengaruh Kontrol Diri Terhadap perilaku Konsumtif Mahasiswa Pengguna E-Commerce, 
Tabel 4.

P-value

\begin{tabular}{lccc}
\hline \multicolumn{1}{c}{ Variabel } & Kontrol Diri & Literasi Keuangan & Perilaku Konsumtif \\
\hline Kontrol Diri & $<0.001$ & & \\
Literasi Keuangan & 0.318 & 0.003 \\
Perilaku Konsumtif & & \\
\hline
\end{tabular}

Sumber : Hasil olah WarPLS, 2021

Hasil uji pengaruh langsung (direct effect) pada Tabel 3 di atas menunjukkan kontrol diri mempunyai nilai koefisien jalur sebesar -0.045 terhadap perilaku konsumtif dan pada Tabel 4 menunjukkan nilai $P$-value $=0.318$ yang berarti tidak signifikan. Hasil uji tersebut dapat dikatakan tidak signifikan dikarenakan didapat nilai $\mathrm{P}$-value $>0.05$. Hal ini mengindikasikan tidak terdapat pengaruh secara langsung signifikan kontrol diri (X) terhadap perilaku konsumtif (Y) sehingga H1 ditolak. H1 ditolak karena variabel kontrol diri tidak mampu memberi pengaruh secara langsung signifikan terhadap variabel perilaku konsumtif. Hal ini selaras dengan penelitian Salsabila dkk. (2019) yang menyatakan kontrol diri tidak mempunyai hubungan dengan perilaku konsumtif mahasiswa Fakultas Hukum UBH pengguna Shoppe. Menurut Salsabila dkk. (2019), kontrol diri bukan merupakan sebuah variabel kuat yang dapat mempengaruhi perilaku konsumtif seseorang.

Ada banyak hal dan beragam faktor yang dapat menjadi pengaruh munculnya perilaku konsumtif. Pendapat Lina \& Rosyid (1997) mengatakan faktor internal dan faktor eksternal dapat menjadi pengaruh munculnya perilaku konsumtif. Faktor internal dapat berupa motivasi, kepribadian, pengamatan, proses pembelajaran, harga diri, dan konsep diri, sedangkan faktor eksternal dapat berupa lingkungan keluarga, kelompok referensi, kelompok sosial kelas sosial dan kebudayaan. Fransisca \& Suyasa (2017) menambahkan perilaku konsumtif juga dapat dipengaruhi oleh konformitas, hadirnya iklan, kartu kredit serta gaya hidup. Banyaknya faktor-faktor yang berasal dari eksternal terutama lingkungan dan kelompok sosial menjadikan kontrol diri sebagai bagian dari faktor internal tidak begitu memberikan pengaruh terhadap perilaku konsumtif mahasiswa pengguna e-commerce di Program Studi Pendidikan Akuntansi Universitas Negeri Surabaya.

Hasil uji pengaruh langsung variabel kontrol diri memiliki nilai koefisien jalur sebesar 0.648 terhadap variabel literasi keuangan. Nilai $P$-value $<0.001$ menunjukkan hasil yang signifikan sehingga $\mathrm{H} 2$ diterima. Hasil uji tersebut mengindikasikan adanya pengaruh secara langsung positif signifikan kontrol diri (X) terhadap literasi keuangan (M) pada mahasiswa pengguna e-commerce yang berarti semakin baik atau tinggi kontrol diri maka akan diiringi pula dengan semakin tingginya literasi keuangan mahasiswa pengguna e-commerce. Hasil pengujian ini sejalan dengan penelitian Susanti (2016) yang menyebut literasi keuangan dapat dipengaruhi oleh kontrol diri dalam membentuk perilaku keuangan mahasiswa menjadi lebih baik sehingga semakin baik atau tinggi tingkat kontrol diri mahasiswa maka akan semakin mempengaruhi pula tingginya tingkat literasi keuangan yang dimilikinya.

Keputusan individu digambarkan oleh kontrol diri lewat pertimbangan kognitif dengan menggabungkan perilaku yang sudah disusun guna mencapai tujuan tertentu sesuai yang diinginkan

Peran Literasi Keuangan Dalam Memediasi Pengaruh Kontrol Diri Terhadap perilaku Konsumtif Mahasiswa Pengguna E-Commerce, Rosana Mu'amala dan Eko Wahjudi 
(Ghufron \& Risnawita, 2010). Pengaruh kontrol diri terhadap literasi keuangan dalam penelitian ini didasarkan pada aspek kontrol diri menurut Averill dalam (Ghufron \& Risnawita, 2010) yang dibagi menjadi kontrol perilaku, kontrol kognitif, dan kontrol keputusan. Bagi mahasiswa pengguna $e$ commerce, kontrol perilaku menggambarkan kemampuan dan perilakunya dalam mengkaji pemasukan serta pengeluaran ketika berbelanja agar sesuai dengan perencanaan keuangan yang dibuat. Kontrol kognitif digunakan untuk membuat keputusan keuangan dengan memikirkan berbagai manfaat yang diperoleh. Mahasiswa akan menggunakan pengetahuan keuangannya untuk menganalisa keuntungan dan manfaat dari tindakan yang diambil, sedangkan kontrol keputusan digunakan untuk mengontrol berbagai impuls atau dorongan yang bertendensi menyebabkan penyimpangan terhadap keputusan keuangan.

Hasil uji pengaruh langsung selanjutnya menunjukkan variabel literasi keuangan (M) mempunyai nilai koefisien jalur sebesar 0.253 terhadap perilaku konsumtif (Y). Nilai $P$-value $<0.05$ yang berarti signifikan menunjukkan bahwa $\mathrm{H} 3$ dapat diterima dalam penelitian. Hasil ini menyimpulkan bahwa terdapat pengaruh secara langsung positif signifikan literasi keuangan (M) terhadap perilaku konsumtif (Y) mahasiswa pengguna e-commerce yang berarti literasi keuangan yang tinggi akan berpengaruh terhadap meningkatnya perilaku konsumtif. Hal ini selaras dengan penelitian Saputri dkk. (2017) yang mengatakan literasi keuangan memiliki pengaruh secara langsung positif signifikan terhadap perilaku konsumtif.

Mahasiswa yang mempunyai tingkat literasi keuangan yang tinggi, perilaku konsumtifnya tetap dapat meningkat karena mahasiswa masih tergolong konsumen tingkat remaja yang biasanya cenderung senang mengikuti tren, mudah terpengaruh oleh lingkungan, senang mengikuti teman, dan sering boros dalam membelanjakan uangnya meskipun mahasiswa memiliki pengetahuan keuangan yang diperoleh dari pendidikan formal atau perkuliahan seperti dari berbagai mata kuliah akuntansi dan ekonomi serta pendidikan informal seperti lingkungan sekitar (orang tua, teman dan pengalaman). Pendapatan mahasiswa umumnya sebagian besar diperoleh dari uang saku yang diberikan orang tua tanpa perlu bekerja sehingga terkadang bisa dengan mudah dihabiskan untuk hal-hal yang konsumtif, oleh karena itu pengetahuan keuangan atau literasi keuangan yang diperoleh mahasiswa dari proses pembelajaran dan pengalaman terkadang masih belum mampu diterapkan secara optimal dalam praktek kehidupan seharihari.

Mahasiswa Pendidikan Akuntansi Universitas Negeri Surabaya secara keseluruhan belum sepenuhnya mampu mempraktekan kemampuan literasi keuangannya untuk menghindari perilaku konsumtif. Hal ini terlihat pada hasil analisis deskriptif penelitian yang menunjukkan bahwa tingkat literasi keuangan mahasiswa pengguna e-commerce di Pendidikan Akuntansi Universitas Negeri Surabaya termasuk dalam kategori tinggi namun tingkat perilaku konsumtifnya tergolong sedang sehingga tidak semua mahasiswa yang mempunyai pengetahuan keuangan yang tinggi mencerminkan pula adanya perilaku konsumtif yang rendah. Kondisi ini bertentangan dengan penelitian Julian dkk. (2015); Ridhayani \& Johan (2020); Dewi dkk. (2017) serta Imawati dkk. (2013) yang mengatakan literasi keuangan mempunyai pengaruh negatif signifikan terhadap perilaku konsumtif dimana semakin tinggi literasi keuangan maka akan semakin menurunkan perilaku konsumtif.

Setelah analisis hasil uji pengaruh langsung maka selanjutnya adalah analisis hasil uji pengaruh tidak langsung (indirect effect) untuk membuktikan hipotesis 4 (H4 ). Pada Tabel 5 dan Tabel 6 akan ditampilkan hasil uji pengaruh tidak langsung (indirect effect) dalam penelitian : 
Tabel 5.

Path Coefficient indirect effect for path 2 segments

\begin{tabular}{lccc}
\hline \multicolumn{1}{c}{ Variabel } & $\begin{array}{c}\text { Kontrol } \\
\text { Diri }\end{array}$ & $\begin{array}{c}\text { Literasi } \\
\text { Keuangan }\end{array}$ & $\begin{array}{c}\text { Perilaku } \\
\text { Konsumtif }\end{array}$ \\
\hline $\begin{array}{l}\text { Kontrol Diri } \\
\text { Literasi Keuangan } \\
\text { Perilaku Konsumtif. }\end{array}$ & 0.164 & & \\
\hline
\end{tabular}

Sumber : Hasil olah WarPLS, 2021

Tabel 6.

$P$-value indirect effect for path 2 segments

\begin{tabular}{lccc}
\hline \multicolumn{1}{c}{ Variabel } & $\begin{array}{c}\text { Kontrol } \\
\text { Diri }\end{array}$ & $\begin{array}{c}\text { Literasi } \\
\text { Keuangan }\end{array}$ & $\begin{array}{c}\text { Perilaku } \\
\text { Konsumtif }\end{array}$ \\
\hline Kontrol Diri & & & \\
Literasi Keuangan & & & \\
Perilaku Konsumtif & $\mathrm{P}<0.006$ & & \\
\hline
\end{tabular}

Sumber : Hasil olah WarPLS, 2021

Pada Tabel 5 di atas telah ditunjukkan hasil uji pengaruh tidak langsung kontrol diri (X) terhadap perilaku konsumtif (Y) menggunakan variabel mediasi literasi keuangan (M) yang mana hasilnya memiliki nilai koefisien jalur sebesar 0.164. Pada Tabel 6, nilai $P$-value sebesar 0.006 menunjukkan hasil yang signifikan. Hasil pengujian tersebut dapat diketahui kontrol diri (X) berpengaruh secara tidak langsung signifikan terhadap perilaku konsumtif (Y) melalui literasi keuangan (M), sedangkan pada hasil sebelumnya telah dijelaskan bahwa pengaruh kontrol diri secara langsung tidak signifikan terhadap perilaku konsumtif sehingga hal tersebut membuktikan variabel literasi keuangan mampu memediasi secara penuh (perfect mediation) pengaruh kontrol diri terhadap perilaku konsumtif mahasiswa pengguna e-commerce serta $\mathrm{H} 4$ dapat diterima.

Kontrol diri yang meningkat akan diiringi pula dengan meningkatnya literasi keuangan sehingga akan mempengaruhi perilaku konsumtif mahasiswa pengguna e-commerce. Hasil ini didukung oleh penelitian Surono et al.,( 2020) yang menyebut kontrol diri tidak cukup untuk menentukan keputusan yang tepat dalam berkonsumsi sehingga dibutuhkan pengetahuan keuangan atau literasi keuangan dalam membuat keputusan yang efektif agar dapat memperoleh utilitas maksimum dari produk yang dikonsumsi untuk meningkatkan kesejahteraan hidup. Hasil ini diperkuat pula oleh penelitian Susanti (2016) yang mengatakan kontrol diri mempengaruhi literasi keuangan mahasiswa, apabila kontrol diri yang dimiliki oleh mahasiswa tinggi atau baik maka akan semakin baik pula tingkat literasi keuangannya. Kontrol diri yang baik bersamaan dengan tingginya tingkat literasi keuangan dapat membuat mahasiswa pengguna $e$ commerce mampu mengelola disposible income yang diperolehnya agar tidak hanya dihabiskan untuk alokasi konsumsi namun dapat didistribusikan pula untuk kegiatan saving di tengah maraknya belanja

Peran Literasi Keuangan Dalam Memediasi Pengaruh Kontrol Diri Terhadap perilaku Konsumtif Mahasiswa Pengguna E-Commerce, 
online melalui e-commerce yang mempengaruhi perilaku konsumtif mahasiswa. Hal ini pun didukung oleh penelitian Widayanti (2019); Indahwati (2020); dan Silalahi (2020) yang juga menyebut literasi keuangan memiliki pengaruh positif signifikan terhadap perilaku konsumtif.

Literasi keuangan yang tinggi dapat beresiko pula meningkatkan perilaku konsumtif mahasiswa karena mahasiswa biasanya memiliki bekal pemahaman keuangan tidak hanya berupa pengelolaan uang, namun juga memiliki pemahaman terhadap penggunaan hutang dan produk keuangan lainnya sehingga jika pengetahuan keuangannya disalahgunakan atau tidak disertai pengendalian diri yang baik dalam berbelanja menggunakan hutang atau produk keuangan tertentu maka akan beresiko meningkatkan perilaku konsumtifnya. Menurut Ridhayani \& Johan (2020), perilaku konsumtif perlu diminimalisir karena dapat menyebabkan masalah keuangan seperti penggunaan kartu kredit yang tidak bijaksana dan diperburuk dengan perkembangan teknologi financial saat ini seperti fasilitas e-money yang memudahkan transaksi serta fasilitas paylater pada e-commerce yang membuat siapapun mudah mengambil pinjaman melalui platform online guna melakukan pembelian dengan skema kredit. Dengan demikian kontrol diri diperlukan untuk mencegah pembelian barang yang tidak rasional karena penggunaan e-commerce bagi mahasiswa, sedangkan literasi keuangan dibutuhkan untuk membantu perencanaan keuangan yang tepat, mengelola anggaran, mempertimbangkan berbagai resiko keuangan serta membuat keputusan yang tepat terkait keuangan dengan bijak sehingga mahasiswa pengguna e-commerce dapat mengelola perilaku konsumsinya agar tidak semakin berperilaku konsumtif.

\section{SIMPULAN DAN SARAN}

Penelitian ini memiliki beberapa kesimpulan yakni (1)kontrol diri tidak dapat mempengaruhi secara langsung perilaku konsumtif, (2)kontrol diri berpengaruh positif signifikan terhadap literasi keuangan, (3)literasi keuangan berpengaruh positif signifikan terhadap perilaku konsumtif, serta (4)literasi keuangan mampu memediasi secara penuh (perfect mediation) pengaruh kontrol diri terhadap perilaku konsumtif mahasiswa pengguna e-commerce di Program Studi Pendidikan Akuntansi Universitas Negeri Surabaya. Adapun penelitian ini hanya menggunakan sampel penelitian dari Program Studi Pendidikan Akuntansi Universitas Negeri Surabaya. Saran bagi peneliti berikutnya diharapkan dapat memperluas cakupan populasi penelitian dengan menambahkan jumlah sampel dari program studi maupun jurusan lainnya di Universitas Negeri Surabaya atau dapat pula peneliti menambahkan sampel yang berasal dari universitas lainnya untuk memperkuat hasil penelitian.

\section{REFERENSI}

Amelia, D. (2019). Hubungan Antara Self Control dengan Perilaku Konsumtif Belanja Online Pada Mahasiswa UNP. Jurnal UNP, 4(1), 1-11.

Anggraini, R. T., \& Santhoso, F. H. (2017). Hubungan antara Gaya Hidup Hedonis dengan Perilaku Konsumtif pada Remaja. Gadjah Mada Journal of Psychology, $131-140$. https://doi.org/https://doi.org/10.22146/gamajop.44104

Anggreini, R., \& Mariyanti, S. (2014). Hubungan Antara Kontrol Diri Dan Perilaku Konsumtif Mahasiswi Universitas Esa Unggul. Jurnal Psikologi Esa Unggul, 12(01), 34-42.

Capuano, A., \& Ramsay, I. (2011). What Causes Suboptimal Financial Behaviour? An Exploration of Financial Literacy, Social Influences and Behavioural Economics. In Melbourne: Corporate Law and Securities

Peran Literasi Keuangan Dalam Memediasi Pengaruh Kontrol Diri Terhadap perilaku Konsumtif Mahasiswa Pengguna E-Commerce, 
Regulation, The University of Melbourne. https://doi.org/https://doi.org/10.2139/SSRN.1793502

Chita, R. C. M., David, L., \& Pali, C. (2015). Hubunngan Antara Kontrol Diri dengan Perilaku Konsumtif Online Shopping Produk Fashion pada Mahasiswa Fakultas Kedokteran Universitas Sam Ratulangi Angkatan 2011. Jurnal E-Biomedik (EBm), 3(1), 297-302.

Dewi, N., Rusdarti, \& Sunarto, S. (2017). Pengaruh Lingkungan Keluarga, Teman Sebaya, Pengendalian Diri Dan Literasi Keuangan Terhadap Perilaku Konsumtif Mahasiswa. Journal of Economic Education, 6(1), $29-35$.

Fattah, F. A., Indriayu, M., \& Sunarto. (2018). Pengaruh Literasi Keuangan dan Pengendalian Diri Terhadap Perilaku Konsumtif Siswa SMA Muhammadiyah 1 Karanganyar. BISE: Jurnal Pendidikan Bisnis Dan Ekonomi, 4(1), 11-21.

Fransisca Riani Roesmania Dewi, \& Suyasa, P. T. Y. S. (2017). Perbandingan Perilaku Konsumtif berdasarkan Metode Pembayaran. Jurnal Phronesis, 7(2), 172-199.

Ghufron, M. N., \& Risnawita, R. (2010). Teori-Teori Psikologi (1st ed.). Yogyakarta: Ar-Ruzz Media.

Hayati, A., Yusuf, A. M., \& Asnah, M. B. (2020). Contribution of Self Control and Peer Conformity to Consumptive Behavior. International Journal of Applied Counseling and Social Sciences, 02(01), 16-24. https://doi.org/10.24036/005344ijaccs

Huston, S. J. (2010). Measuring Financial Literacy. Journal of Consumer Affairs, 44(2), $296-316$. https://doi.org/10.1111/j.1745-6606.2010.01170.x

Imawati, I., Susilaningsih, \& Ivada, E. (2013). Pengaruh Financial Literacy Terhadap Perilaku Konsumtif Remaja pada Program IPS SMA Negeri 1 Surakarta Tahun Ajaran 2012/2013. Jupe UNS, 2(1), 48-58. https://doi.org/10.1088/1751-8113/44/8/085201

Julian, E., Ananda, N. A., \& Andriani, S. (2018). Analisis Tingkat Literasi Keungan Terhadap Perilaku Konsumtif pada Remaja Sumbawa. Jurnal Manajemen Bisnis-UTS, 1(2), 1-5. https://doi.org/https://doi.org/10.37673/jmb.v1i2.15

Juliardi, D., Rafsanjani, M. A., Suparti, \& Praherdhiono, H. (2018). Determinant of Consumptive Behavior : Study on Accountancy Colleger. Atlantis Press, 164(1), 178-181. https://doi.org/https://dx.doi.org/10.2991/icli17.2018.34

Kartini, S. (2010). Konsep Konsumsi dan Investasi. Semarang: PT Bengawan Ilmu.

Kumalasari, D., \& Soesilo, Y. H. (2019). Pengaruh Literasi Keuangan, Modernitas Individu, Uang Saku, dan Kontrol Diri Terhadap Perilaku Konsumtif Mahasiswa Prodi S1 Pendidikan Ekonomi Universitas Negeri Malang. JPE: Jurnal Pendidikan Ekonomi, 12(1), 61-71.

Lina, \& Rosyid, H. F. (1997). Perilaku Konsumtif Berdasarkan Locus of Control Pada Remaja Putri. Psikologika, 2(4), 5-13.

Peraturan Otoritas Jasa Keuangan. (2016). Peningkatan Literasi dan Inklusi Keuangan di Sektor Jasa Keuangan Bagi Konsumen dan/atau Masyarakat. Journal of Chemical Information and Modeling, 53(9), 1689-1699. https://doi.org/10.1017/CBO9781107415324.004

Putri, S. F., Widodo, J., \& Martono, S. (2016). Pengaruh Literasi Keuangan Melalui Rasionalitas Terhadap Perilaku Konsumtif (Studi Kasus Siswa Kelas XI Ilmu Sosial SMA Negeri se-Kota Semarang). Journal of Economic Education, 5(2), 179-192.

Rachmawati, A. L. (2019). Analisis Pengaruh E-Commerce terhadap Perilaku Konsumtif Mahasiswa (Studi Kasus pada Mahasiswa di Prodi Manajemen Universitas Tidar). Jurnal Online Mahasiswa Manajemen, 1(1), 1-5.

Rerung, R. R. (2018). E-Commerce, Menciptakan Daya Saing Melalui Teknologi Informasi (1st ed.). Yogyakarta: Deepublish.

Research, A. B. I. (2019). Perilaku dan Preferensi Konsumen Millennial Indonesia terhadap Aplikasi E-Commerce 2019. Jakarta.

Research, A. B. I. (2020). Indonesia Gen Z and Millenial Report 2020: The Battle Of Our Generation. Jakarta.

Ridhayani, F., \& Johan, I. R. (2020). The Influence of Financial Literacy and Reference Group toward Con sumptive Behavior Across Senior High School Students. Journal of Consumer Sciences, 05(01), $29-45$. https://doi.org/https://doi.org/10.29244/jcs.5.1.29-45

Roestanto, A. (2017). Literasi Keuangan. Yogyakarta: Istana Media.

Salsabila, R., Nio, S. R., \& Padang, U. N. (2019). Hubungan Kontrol Diri dengan Perilaku Konsumtif Mahasiswa Fakultas Hukum UBH Pengguna Shopee. Jurnal Riset Psikologi, 4, 1-12. https://doi.org/http://dx.doi.org/10.24036/jrp.v2019i4.7969

Santrock, J. W. (2017). Psikologi Pendidikan (2nd ed.). Jakarta: Kencana.

Saputri, H. M., Siswandari, \& Muchsini, B. (2017). Pengaruh Financial Literacy Terhadap Perilaku Konsumtif Siswa SMA Muhammadiyah Program Khusus (PK) Kottabarat Surakarta. Jurnal “Tata Arta” UNS, 3(2), 8594.

Peran Literasi Keuangan Dalam Memediasi Pengaruh Kontrol Diri Terhadap perilaku Konsumtif Mahasiswa Pengguna E-Commerce,

Rosana Mu'amala dan Eko Wahjudi 
Solimun, Fernandes, A. A. R., \& Nurjannah. (2017). Metode Statistika Multivariat Permodelan Persamaan Struktural (SEM) Pendekatan WarpLS. Malang: UB Press.

Sugiono. (2017). Metode Penelitian Kuantitatif, Kualitatif, dan R\&D. Bandung: Alfabeta CV.

Sultan, A. J., Joireman, J., \& Sprott, D. E. (2012). Building Consumer Self-Control: The Effect of Self-Control Exercises on Impulse Buying Urges. Marketing Letters, 23(1), 61-72. https://doi.org/10.1007/s11002-0119135-4

Sumartono. (2002). Terperangkap dalam Iklan: Meneropong Imbas Pesan Iklan Televisi. Bandung: Bandung: Alfabeta.

Surono, Bahruddin, M., \& Habibi, A. (2020). Effectiveness Financial Literacy Toward Making Decision of Consumer Behavior. Buletin Studi Ekonomi, 25(1), 99-111. https://doi.org/https://doi.org/10.24843/BSE.2020.v25.i01.p06

Susanti. (2016). Pengaruh Locus of Control Internal dan Pendapatan Terhadap Literasi Keuangan Mahasiswa. JPEK UNESA, 4(1), 5-17. https://doi.org/http://dx.doi.org/10.26740/jepk.v4n1.p5-17

Tambunan, T. T. H. (2001). Perekonomian Indonesia: Teori dan Temuan Empiris. Jakarta: Ghalia Indonesia.

Tripambudi, B., \& Indrawati, E. S. (2018). Hubungan Antara Kontrol Diri Dengan Perilaku Konsumtif Pembelian Gadget Pada Mahasiswa Teknik Industri Universitas Diponegoro. Empati, 7(2), 189-195.

Vohs, K. D., \& Faber, R. J. (2007). Spent Resources: Self-Regulatory Resource Availability Affects Impulse Buying. Journal of Consumer Research, 33(4), 537-547. https://doi.org/10.1086/510228 